\title{
Binahong as a Facial Skin Care Mask
}

\author{
Suhartiningsih, Maspiyah, Dewi Lutfiati \\ Department of Home Economics \\ Universitas Negeri Surabaya \\ Surabaya, Indonesia \\ suhartiningsih1957@yahoo.com
}

\begin{abstract}
Mask is a cosmetic used on the last stage in the treatment of facial skin. It works in depth because it can pick up the dead skin cells and refine the skin. This research aimed to know 1) proportion of binahong leaves extract and tapioca flour as a traditional facial mask in terms of aroma, color, texture, favorite, and its stickiness 2) responses of panelists after using traditional mask for facial skin care to create cold sensation and lighten the skin and 3) storage duration of this traditional mask. The proportion of binahong leaf extract and tapioca flour were $(20 \mathrm{~g}: 80 \mathrm{~g})$; $(25 \mathrm{~g}: 75 \mathrm{~g})$; and $(30 \mathrm{~g}: 7 \mathrm{og})$. The data were collected through observation in physical properties test conducted by 30 panelists. Data analysis used statistical anova (one way). The results of the statistical analysis stated that proportion of binahong leaves extract and influence of real tapioca to quality face mask covering the traditional aroma, color, stickiness, cold sensation, and panelists fondness. However, the texture and brighten the skin effect did not differ significantly. The results of the best masks on the proportion of binahong leaves was $20 \mathrm{~g}$ with $80 \mathrm{~g}$ tapioca which produced distinctive aroma of binahong leaves, white-yellowish, smooth texture, very attached to the skin, and favoured by the panelists. Maximum storage duration was 2 weeks. Microbiological test results showed that the microbe discovered was $10^{4} 2$. It is still in normal conditions because the limit of minimum microbes set by SNI is $10^{5}$.
\end{abstract}

Keywords-cosmetics; facial masks; binahong leaf extract

\section{INTRODUCTION}

Cosmetic facial mask is used in the final stage in the treatment of facial skin. Mask including depth cleansing cosmetics are cosmetics that work in depth because it can raise dead skin cells. The characteristics of the face mask are as follows: it can be applied on the skin, tightens the skin, and contains beneficial substances for skin. In the market, there are many types of mask offered, including powder mask, cream mask, gel masks, and paper or cloth masks. However, among those types of mask, the most popular is powder mask. Powder mask can be produced in a modern apart can also be made traditionally. Standardization of powder mask in general are ruled as follows: a) Standard dosage facial mask according to SNI 16-6070 1999 is to tight the skin and give cleaning effect. b) The water content of the required generally is not more than $10 \%$ [1]. c) Terms levels of salicylic acid in a cosmetic as stated by Decree of the General Director of Drug and Food Control Department of Health of the Republic of Indonesia No. HK.00.05.4.1745 dated May 5, 2003, shoul not be more than 2\%. d) According to the Decree of the General Director of Drug and Food Control Department of Health of the Republic of Indonesia No. HK.00.06.4.02894, standards on the preparation of test microbial face mask with a maximum total plate count is $10^{5}$.

Tapioca can be used as ingredient in producing traditional mask. Basically, tapioca is a cold ingredient that may chill the skin quickly. The function of tapioca in producing facial mask is as an adhesive that when the mask is applied to the skin, it will stick and tighten the skin. [2] research revealed that traditional mask from tapioca and betel leaf extract were favored by the respondents because it created distinctive aroma, smoothed, tightened and refreshed the skin. There are various traditional masks on the market, such as seaweed mask, chocolate mask, vanilla mask, yam mask, greentea mask and others. Masks made from traditional materials have many benefits and are safe for the skin because they do not have harmful effect. Besides tapioca as the main ingredient, binahong leaves extracts are used as the additives. Binahong leaves can be useful for the skin for its ability to dry acne and reduce the black spots on the skin [3]. The contents of antioxidants and vitamins which are essential for skin nutrients such as, vitamin B1, B2, C, E, A, and $\mathrm{K}$ are adventageous for skin health. The A. cordifolia leaves and T. tuberculata stem extract at doses 1, 2, 4, and 8 times of MIC may inhibit bacteria growth after 4 hours incubation period. Ciprofloxacin, as standard drug, shows high rate of killing during the initial exposure time, except for $\mathrm{P}$. aeruginosa. This finding suggests that A. cordifolia leaves and T. tuberculata stem extract may act as bacteriostatic and only inhibit the growth of the bacteria [4].

Binahong leaves contain saponins, alkaloids and polyphenols [5] Saponins are surface active compounds and acts like soap. Filtering saponins will give better results as an antibacterial when using polar solvents such as ethanol $70 \%$ [6] In hydrolysis, saponin yields the aglycone called sapogenin (as cortisone). Based on the structure, there are two steroid namely saponin and triterpenoid. Steroidal saponins are found in monocot plants, and triterpenoid saponins contain in dicotyledonous plants [7].Saponins stimulate the formation of collagen, the structural protein that plays a role in wound healing [8].

Polyphenols are compounds with more than one core benzene. Polyphenols are soluble in water because it is polar. Polyphenols can be detected by adding iron (III) chloride and 
reducing power test, with the addition of Fehling $\mathrm{A}$ and Fehling B on the extract to form a brick-red precipitate [9]. The results empirically proved [10] that topical administration of binahong leaves could heal burns in mice. The result is in line with [11] research about binahong leave gel which could cure acne.

Tapioca is a starch extracted by water from cassava tubers (cassava). Once filtered, the liquid portion separated by the dregs. Liquid distillate is then deposited. The part that settled in it then dried and milled to obtain fine white starch granules. In obtaining starch from cassava (tapioca), it should be considered the age or maturity of the cassava plant. Tapioca has many names in several parts of the world, such as mandioca tapioca, aipim, macaxeira, manioca, boba, and yuca. Tapioca is water-soluble so it is used as a thickening [12].

Tapioca is relatively inexpensive and has other benefits, especially for the beauty. It is known to use as yam face mask due to its antioxidant benefit. Cassava face mask are able to soften and brighten face and remove acne scars [13]. Another benefit of the starch is as prickly heat drugs because the tapioca may give cold sensation when applied to the skin.

Quality is the final characteristics which support the ability of certain product to meet the needs. Quality is often interpreted everything that satisfies consumers or in accordance with the requirements or needs [14]. The product is anything that can be offered to a market to meet demand. So, basically the product is anything which can meet the needs or demans of the people or consumers. The quality of products is a guarantee that the products offered to consumers have actually been through the process of measuring and testing carefully and rationally that it deserves to use [15]. This research aimed to know: 1) proportion of binahong leaves extract and tapioca flour as a traditional facial mask in terms of aroma, color, texture, favorite, and its stickiness 2) responses of panelists after using traditional mask for facial skin care to create cold sensation and lighten the skin and 3) storage duration of this traditional mask.

\section{METHODS}

In this study, the control varables were the types of tapioca and methods of making binahong leaves extract. The equipment used in producing masks should be the same, clean, and in accordance with its function. Sifting process in producing masks was done 3 times, i.e. after mixing and after drying, and the final outcome of face mask. Physical properties were conducted in the science laboratory of the Department of Family Welfare Education Faculty of Engineering, State University of Surabaya. Microbiology test was in the Laboratory of Microbiology. Research was carried out from March to November, 2016.

The process of making traditional face masks of binahong leaves extract and tapioca were 1) Making binahong leaves extract: binahong leaves were washed and cut into small pieces and then dried at a temperature of $250 \mathrm{C}$ wind-270C for 5 days. After drying, put the leaves in a blender to make them into powder and then sifted. The process of extraction was 50 grams of leaf powder binahong wrapped in filter paper and put the pumpkin Soxhler. Then, put as much as $300 \mathrm{ml}$ ether extracted for 3-4 hours until the color solvent vapor that entered into the boiling flask clear and ethers in the boiling flask were solid green resulting $200 \mathrm{ml}$ extract. 2) The next step was weighing the binahong leaves extract and then pouring in each cup. It was 20 grams for X1, 25 grams for cup $\mathrm{X} 2$, and 30 grams for cup X3. 3) The following step was weighing tapioca. It was 80 grams for $\mathrm{X} 1,75$ grams for $\mathrm{X} 2$, and 70 grams for X3.4) The next step was mixing binahong leaf extract and tapioca in each cup. 5) After the third treatment in the mix, the three treatments were inserted into the oven with a temperature of $40^{\circ} \mathrm{C}$ until it dried. 6) After the third treatment of dry, pulverized using a blender, then sieve again. 7) once in the sifter, the three treatments put back into the oven at the same temperature until completely dried.

If the mask was completely dry and then cooled. The data collection method used was observation. Observation methods performed to test the physical properties of traditional masks including aroma, color, texture, stickness, and panelists' favorites. Number of panelists in this study were 30 people consisting of trained panelists (lecturer) and semi-skilled (student cosmetology).

Data analysis technique used was single classification analysis of variance (Single ANOVA). If the results showed no real influence, then it would be continued with Duncan test. The best mask was determined by the Duncan test resulted aroma, color, texture, stickness, and the level of preference. The storage duration of the mask was analyzed using microbiological test.

\section{RESULTS AND DISCUSSION}

\section{A. Description of Observations}

The average value (mean) of the physical properties of a traditional face mask covered aroma, color, texture, stickness and panelists' preference on each treatment.

Descriptive resulted that the panelists' favorite traditional masks covering, aroma, color, texture, stickness, cold sensation and brighten the skin was the proportion of $\mathrm{X} 2$, binahong leaves extract: tapioca (20:80).

\section{- Aroma}

It is used to indicate a significant difference between the tree proportions of binahong leaves and tapioca. X1 was the least flavorful from the $\mathrm{X} 2$ and $\mathrm{X} 3$. This is because the more the number of binahong leaves extract, the more aroma of binahong produced.

\section{- Color}

Anova test result about color, showed no significant difference among the three proportions binahong leaves and tapioca. Color differences became apparent on the Duncan test results the following:

Duncan test results found that the proportion of binahong leaves extract and tapioca produced different effects. 
Proportion X3 (30 grams of binahong leaves extract: 70 grams of tapioca) produced mastic concentrated, X2 (25 grams of binahong leaves extract: 75 grams of tapioca) produced light yellow color, while the proportion of X1 (20 grams of binahong leaves extract: 80 grams of tapioca) produced somewhat whitish yellow color. The more the binahong leaves extract given, the more dark yellow color appeared. Color mask which generated in this study were somewhat whitish pale yellow to light yellow slab. The mask color was derived from yellow of binahong leaves extract and white color was formed by the starch. So, if the two colors were mixed, then they produced mastic somewhat whitish to pale yellow slab.

The yellow color of the leaves extract was derived from binahong substance which was useful as an antioxidant, anthocyanin. Anthocyanins are the pigments from the group of water-soluble flavonoids. Anthocyanins and other flavonoids are helpful in several medical areas as its function as an anticarcinogen, antibacterial, antiviral, and antioxidant [16].

\section{- Texture}

It is showed that the proportion of binahong leaves extract and tapioca had no effect on the texture of traditional face mask, with 0.247 significance was greater than $\alpha=0.05$. So, the hypothesis about the effect on proportion of binahong leaf extract and tapioca on the texture was rejected. The texture was not significantly different in the respective proportions of the traditional face mask.

This is because the masks were made from the same binahong leaves extract for the respective propostion X1, X2 and X3. Tapioca which has a smooth texture is reinforced with a standard fineness of starch contained in SNI 01-3451-1994. It was stated that $99 \%$ of tapioca flour escaped sifter. Physical properties of the texture mask to produce masks in proportion $\mathrm{X} 1, \mathrm{X} 2$ and $\mathrm{X} 3$ had the same criteria on smooth texture.

\section{- $\quad$ Stickiness}

The results of a single test Anova on the proportion of binahong leaves extract and tapioca effect on the stickiness of the mask was shown with a significance of .000

So, the hypothesis that there was influence on the proportion of binahong leaves extract and tapioca in terms of stickiness was accepted. It can be concluded that the greater number of binahong leaves produced low stickiness. All of the three products, after being mixed with rose water, they could be sticked to the skin as a function of tapioca in the mask itself as adhesives and thickeners. This is supported [17] that the tapioca is used as thickeners, fillers, and binder in food industry. After the mask was applied to the skin, it gave cold and dry sensation at the same time to create tight sensation. In accordance with the standard dosage according to SNI 166070-1999 concerning face mask, when it is applied to the skin, it will feel cold and create tight sensation.

\section{- Cold sensation}

Results of statistical analysis on the cold sensation which given by the traditional masks are as follows. In the table 6 , it can be seen that the proportion of binahong affected to the coldness of this traditional mask. Duncan Test results showed the more amount of tapioca, the more cold sensation it could be. This is due to cassava extracts which is useful as an antioxidant. Tapioca in face mask is useful to soften and brighten the face, and remove acne scars [18]. Another benefit of the starch is as prickly heat drugs, because the tapioca will create cold sensation when applied to the skin.

\section{- Panelists' preference}

Based on Anova single test conducted on a face mask products, it can be seen from the level of preference of panelists that there are significant proportions binahong leaf extract and tapioca flour to A panelist

ANOVA test results on the level of A panelist single traditional mask to produce a noticeable effect which can be shown with a significance of 0.000 . A traditional mask level is influenced by the proportion of binahong leaves extract and tapioca. Duncan test conducted to determine differences in the level of A panelist on binahong leaves mask that the less binahong leaves increasingly favored panelists.

This is consistent with the expected outcomes traditional mask, that mask that both meets the criteria of a yellowish white color, unique aroma of traditional materials, firmly attached to the skin and serve as fasteners. The more binahong leaf extract, the more flavorful the typical binahong leaves. The more properties and inherent, the more panelists preferred.

\section{- Storage duration}

The results of microbiological tests on the mask X1 showed that until the first week, the microbial was $10^{2}$. In the second week, there were a number of $10^{4}$ colonies of microbes. This indicated that the mask could still be used until the second week. This is because the microbial growth is still within the limits of the standards set by the Director General of Drug and Food Control Department of the Republic of Indonesia Number: HK.00.06.4.02894 with a maximum of $10^{5}$.

Microbial growed in a short time because the mask was made traditionally without any preservatives such as ethanol, methyl paraben, propyl paraben, commonly used in facial masks product [19].

\section{CONCLUSIONS}

Based on the research results, it can be concluded that: proportion of binahong leaves extract and influence of tapioca to quality of face mask covering the traditional aroma, color, stickiness, cold sensation, and panelists' fondness. However, the texture and brighten the skin effect did not differ significantly. Traditional face masks were good and preferably for the panelists, storage duration was up to two weeks, as in week three the number of microbes has exceeded the threshold (countless). 


\section{REFERENCES}

[1] Afrillia Nuryanti Garmana, Elin Yulinah Sukandar, Irda Fidrianny, 2014, Activity of Several Plant Extracts Against Drug-sensitive and Drug-resistant Microbes, Procedia Chemistry 13 ( 2014 ) 164 - 169.

[2] Anjani, Shelma. 2013. Effect of Proportion Leather Watermelon and Tomato on the Result So Traditional Face Mask. Thesis (unpublished). Surabaya: Faculty of Engineering, State University of Surabaya.

[3] Annisa, N, 2007. Activation Test Antibacterial water extract of leaves binahong against bacteria Klebsiella pneumoniae ATCC 6633 and Bacillus Bustillis Phytochemical screening along with the test tubes. Journal online. Faculty of Pharmacy. Airlangga.

[4] Anonim,1981, Utilization of Medicinal Plants, Directorate General of Food and Drug Administration, Department of Health of the Republic of Indonesia p. 19, 38.43.

[5] Dwikarya, Maria, 2010. Skin Care and Face, Jakarta: Kawan Pustaka

[6] Dryer, D. L., et al., 1998, Testing a New Alcohol Free Had Sanitizer to Combat Infection, AORN Journal, Vol. 68, No. 4, p. 239 - 251.

[7] Fauzi, Ridwan Aceng dan Nurmalina, Rina.2012. Merawat Kulit \& Wajah. Jakarta: PT Elex Media Komputindo.
[8] Kartodimedjo, Sri. 2013. Cantik Dengan Herbal Rahasia Puteri Keraton. Yogyakarta : Citra Media Pustaka.

[9] Khunaifi, Mufid, 2010. Uji Aktivasi Antibakteri Ekstrak Daun Binahong (Anredera Cordifolia (Ten) Steenis terhadap Bakteri Stophylococcus aureus dan Pseudomonas aeruginosa, e-journal online UIN Maulana Malik Ibrahim Malang

[10] Rachmawati S. 2007. Studi Mikroskopi, dan skrining fitokimia Daun Binahong. Analis Kesehatan Sain Vol 01 No 02 2002. ISSN 2302-3635

[11] Rostamailis. 2005. Penggunaan Kosmetika, Dasar Kecantikan Dan Berbusana Yang Serasi. Jakarta. PT Rineka cipta.

[12] Sari, Retno., Dewi I. and Noorma R., 2004, Pemanfaatan Sirih sebagai Sediaan Hand Gel Antiseptic: I. Studi Formulasi, Laporan Penelitian, Fakultas Farmasi,Universitas Airlangga.

[13] Sasri, N.W, 2013. Pengaruh Proporsi Puree Stroberi dengan Tapioka terhadap Kualitas Sediaan Masker Tradisional. Journa onlinel FT Unesa

[14] Umar, Ani, 2002. Pengaruh Pemberian Ekstrak daun binahong terhadap Kesembuhan Luka Infeksi Staphylococcus aureus pada mencit. 